\title{
A GARANTIA DO PRINCÍPIO CONSTITUCIONAL DA PRESUNÇÃO DE INOCÊNCIA (OU DE NÃO CULPABILIDADE): UM DIÁLOGO COM OS DIREITOS E GARANTIAS FUNDAMENTAIS
}

\author{
THE CONSTITUTIONAL PRINCIPLE OF PRESUMPTION OF INNOCENCE \\ WARRANTY (OR OF NON CULPABILITY): A DIALOGUE WITH THE RIGHTS AND \\ FUNDAMENTAL WARRANTIES
}

Deilton Ribeiro Brasil

\begin{abstract}
Pós-Doutorando em Direito Constitucional pela UNIME-IT. Doutorado em Direito pela UGF-RJ. Mestrado em Direito pela FDMC. Professor do PPGD - Mestrado em Direito Proteção dos Direitos Fundamentais e Graduação da Universidade de Itaúna-UIT e do Instituto de Ensino Superior Presidente Tancredo de Almeida Neves-IPTAN.

E-mail: deilton.ribeiro@terra.com.br
\end{abstract}

Recebido em: 07/08/2016

Aprovado em: 22/09/2016

Doi: $10.5585 / \mathrm{rdb} . v 15 \mathrm{i} 6.457$

RESUMO: O princípio da presunção de inocência se insere entre as garantias processuais do devido processo legal e das garantias fundamentais. Tal norma, prevista em atos normativos internacionais e na legislação infraconstitucional está sendo reinterpretada no sentido de sua relativização conforme a essência e o contexto que melhor exprimem os valores da Constituição Federal brasileira. No julgamento do HC 126.292/SP, o Supremo Tribunal Federal modificou sua jurisprudência e firmou o entendimento no sentido de permitir a execução provisória da pena após a confirmação de condenações criminais em segunda instância. Na Medida Cautelar no HC 135.100/MG, o Ministro Celso de Mello entendeu que a execução provisória da pena pelo TJMG, em decorrência de condenação criminal em primeira instância, ainda recorrível, que afasta presunção de inocência e faz prevalecer a presunção de culpabilidade constitui-se em uma inversão inaceitável por ser uma prerrogativa essencial que somente se descaracteriza com o trânsito em julgado da condenação criminal. Aduz ainda pela inaplicabilidade, ao caso, do julgamento Plenário do HC 126.292/SP que foi proferido em processo de perfil meramente subjetivo, desvestido de eficácia vinculante, ou melhor, não pode ser considerada um precedente, e muito menos um "precedente vinculante" atuando somente como referência paradigmática, e não como pauta vinculante de julgamentos o que não se impõe à compulsória observância dos juízes e Tribunais em geral. A pesquisa é de natureza teórico-bibliográfica seguindo o método descritivo-analítico que instruiu a análise de leis relacionadas ao tema, bem como a doutrina que informa os conceitos de ordem dogmática.

Palavras-chave: Princípio da presunção de inocência; Direitos e garantias fundamentais. Relativização; Eficácia vinculante.

ABSTRACT: The presumption of innocence principle operates itself between the procedural guarantees of due process of law and of the fundamental warranties. Such standard, proposed in international normative acts and in the infraconstitutional legislation is being reinterpreted in the increasing of its relativization pursuant to the substance and the context that better express the values of the Federal Constitution. In the trial of habeas-corpus 126.292/SP, the Federal Supreme 
Court (STF) has broadened its jurisprudential analysis and adopted an understanding in order to allow the provisional enforcement after the criminal conviction in second instance court. In the precautionary measure in HC 135.100/MG, the Justice Celso de Mello understood that the provisional execution of the sentence by the Justice Court of Minas Gerais, in result of firstinstance criminal condemnation, still challengeable, which dispels presumption of innocence and prioritizes the presumption of culpability constitutes in an unacceptable inversion for being an essential prerogative that only disfigures itself with the criminal condemnation sentence rendered final. Still provided by the inapplicability, in case, of the judgment of the plenary of HC 126.292/SP that was delivered in process of a mere subjective profile, without a binding effect acting only as paradigmatic reference, and not as binding agenda of judgments that does not impose itself to the compulsory observance of the judges and Courts in general. It's a theoreticalbibliographical-natured research guided by a descriptive-analytical method about related laws, as well as the doctrine that informs the concepts of dogmatic order.

Keywords: Principle of presumption of innocence; Rights and fundamental warranties; Relativization; Binding effectiveness.

SUMÁRIO: Introdução; Da metodologia utilizada; Um breve escorço histórico do Princípio da Presunção de Inocência (ou de não culpabilidade); A Convenção Americana sobre Direitos Humanos; A Natureza Jurídica da Presunção de Inocência (ou de não culpabilidade); Os Direitos Fundamentais como Direitos Restringíveis; Os limites dos Direitos Fundamentais; A Derrotabilidade (ou superabilidade) das normas de Direitos Fundamentais; O princípio da Presunção de Inocência (ou da não culpabilidade) na interpretação do STF: O caso do julgamento do HC 126.292; A posição contrária do Ministro Celso de Mello no julgamento da Medida Cautelar no HC 135.100/MG; Considerações Finais; Referências.

\section{INTRODUÇÃO}

Para Gomes (1999, p. 109), o princípio da presunção de inocência (ou de não culpabilidade), do ponto de vista extrínseco (formal) configura um direito constitucional fundamental, inserido no rol dos direitos e garantias fundamentais da pessoa (art. $5^{\circ}, \mathrm{CF}$ ) e, do ponto de vista intrínseco (substancial), é um direito de natureza predominantemente processual, com repercussões inequívocas no campo probatório, das garantias (garantista) e de tratamento do acusado.

No campo do direito material, a projeção do preceito no âmbito de interpretação das leis penais e de limitação à atividade legislativa. Por fim, aponta as características das garantias "não jurisdicionais", tais como: a eficácia direta e imediata do preceito e sua força vinculatória de todos os poderes (públicos e particulares) e das garantias "jurisdicionais", o acesso à jurisdição, em face da não observância do direito fundamental e o controle de constitucionalidade das leis, que obriga o acatamento à primazia das normas constitucionais (GOMES, 1999, p. 109), (VARALDA, 2007, p. 49), (CARRIÓ, 1979, p. 22-25).

É certo que as presunções são normas de comportamento, em que o legislador formula regras de "dever ser" e estão fundamentadas em valores ideológicos e técnicos. Desse modo, para a apreciação do alcance da presunção de inocência, deve-se considerar principalmente o seu valor ideológico, ao tempo em que exprime uma orientação do legislador, ou seja, a garantia da posição de liberdade do acusado diante do interesse coletivo à repressão penal. Neste aspecto, o princípio se impõe não apenas no momento da decisão judicial, senão também como regra de tratamento do suspeito, que não pode tão-somente igualar-se ao culpado, por se tratar efetivamente de suspeito, indiciado, imputado ou réu (VARALDA, 2007, p. 50). 
O preceito vem referido especialmente à condição de não culpabilidade do cidadão colocado diante do poder punitivo do Estado, vedadas quaisquer formas de tratamento que impliquem em equiparação à situação oposta, o que não implica em vedação à adoção de medidas cautelares investigatórias (GOMES FILHO, 1992, p. 62-63 e 71). Assim, são ilegítimos quaisquer efeitos negativos contra a efetiva situação do indivíduo na sociedade, ou seja, a violação à presunção de inocência se caracterizaria tão-somente na adoção de medidas cautelares restritivas de direitos fundamentais desprovidas de indícios suficientes de autoria e prova de materialidade (VARALDA, 2007, p. 51).

\section{DA METODOLOGIA UTILIZADA}

O método utilizado para a realização do trabalho foi descritivo-analítico com a abordagem de categorias consideradas fundamentais para o desenvolvimento do tema - como o arcabouço jurídico que pavimenta a teoria dos direitos e garantias fundamentais, o princípio da presunção de inocência (ou da não culpabilidade) e os direitos fundamentais como direitos restringíveis. Os procedimentos técnicos utilizados na pesquisa para coleta de dados foram a pesquisa bibliográfica, a doutrinária e a documental. O levantamento bibliográfico forneceu as bases teóricas e doutrinárias a partir de livros e textos de autores de referência, tanto nacionais como estrangeiros. Enquanto o enquadramento bibliográfico utiliza-se da fundamentação dos autores sobre um assunto, o documental articula materiais que não receberam ainda um devido tratamento analítico. A fonte primeira da pesquisa é a bibliográfica e a jurisprudência que instruíram a análise da legislação constitucional e a infraconstitucional, bem como a doutrina que informa os conceitos de ordem dogmática.

\section{UM BREVE ESCORÇO HISTÓRICO DO PRINCÍPIO DA PRESUNÇÃO DE INOCÊNCIA (OU DE NẪO CULPABILIDADE)}

A primeira Declaração de Direitos Fundamentais, em sentido moderno, foi a Declaração do Bom Povo da Virgínia, que era uma das treze colônias inglesas da América. Datada de 12 de janeiro de 1776, anterior, portanto, à Declaração de Independência dos Estados Unidos da América, foi inspirada nas teorias de Locke, Rousseau e Montesquieu, baseada especialmente nos escritos de Jefferson e Adams, colocados em prática por James Madison e George Mason (SILVA J., 2000, p. 153).

A Declaração de Virgínia abarcava as bases dos Direitos do Homem, especialmente assegurando o direito de defesa nos processo criminais, bem como julgamento célere por júri imparcial, posto que ninguém seria privado de sua liberdade, exceto por lei da terra ou julgamento de seus pares. Prestigiava-se a observância da necessidade de defesa, até como um requisito de um processo justo, reconhecido como devido processo legal. Essa Declaração ainda vedava a expedição de mandado geral de busca ou detenção, sem especificação exata e a prova do crime que gerou tal ordem judicial. Ainda se pode concluir que já existia uma priorização, para não se partir de uma presunção absoluta de culpabilidade do cidadão, havendo um abrandamento da norma, pela presunção, de que possivelmente o cidadão possa ser inocente de imputações feitas em face de sua pessoa (BENTO, 2007, p. 37).

A Declaração dos Direitos do Homem e do Cidadão de 1789 proclamou em seu art. $9^{\circ}$ que "todo acusado se presume inocente até ser declarado culpado e, se julgar indispensável prendê-lo, todo o rigor não necessário à guarda de sua pessoa, deverá ser severamente reprimido pela lei".

O princípio da presunção de inocência contido na Declaração dos Direitos do Homem e do Cidadão de 1789 referia-se principalmente ao tratamento do acusado no curso do processo, ou 
seja, presumia-se inocente até a declaração de sentença judicial, em que haveria uma decisão de condenação ou absolvição. Disso decorrem limitações às restrições dos direitos individuais, em especial às medidas cautelares durante a fase instrutória, tais como a prisão preventiva sem prazo certo e a aplicação de formas de antecipação de pena, como suplícios. O processo inquisitório dá lugar ao processo penal acusatório, com uma fase preliminar escrita, secreta e sem contraditório e uma fase instrutória, com a oralidade, a publicidade e o contraditório. Isso denotou a coibição tanto da diminuição social, moral e física do acusado, que passou a ser tratado como se fosse inocente, quanto da aplicação de qualquer medida restritiva de direitos com função de sanção, ou seja, como antecipação da pena (VARALDA, 2007, p. 20-21).

A Declaração Universal dos Direitos do Homem de 1948 enfatizou que:

Art. 11.

1. Todo ser humano acusado de um ato delituoso tem o direito de ser presumido inocente até que a sua culpabilidade tenha sido provada de acordo com a lei, em julgamento público no qual the tenham sido asseguradas todas as garantias necessárias à sua defesa.

2. Ninguém poderá ser culpado por qualquer ação ou omissão que, no momento, não constituíam delito perante o direito nacional ou internacional. Também não será imposta pena mais forte do que aquela que, no momento da prática, era aplicável ao ato delituoso.

Bobbio (1992, p. 30), salienta que a DUDH contém em germe a síntese de um movimento dialético, que começa pela universalidade abstrata dos direitos naturais, transfigura-se na particularidade concreta dos direitos positivos, e termina na universalidade não mais abstrata, mas também concreta, dos direitos positivos universais.

Deflui daí que a Declaração Universal de Direitos Humanos cingiu-se à regra probatória ou de juízo a interpretação da presunção de inocência, ao impor à acusação o ônus da prova sobre o fato criminoso e culpabilidade do acusado; a vedação de produção de prova contra si e o direito ao silêncio do acusado e a absolvição em caso de dúvida do juiz com a análise das provas (VARALDA, 2007, p. 28-29).

Nesse sentido, Vilela (2005, p. 60) registra que de acordo com o princípio de presunção de inocência ninguém pode ser perseguido a não ser nos casos e de acordo com a forma prevista na lei; ninguém poderá ser julgado sem que tenha sido devidamente citado e chamado; enquanto o imputado não seja declarado culpado por uma decisão com força de caso julgado considera-se inocente; o acusado tem o direito de apresentar a sua defesa livremente, e de discutir os elementos de prova contra si reunidos; a prova incumbe à parte que acusa e em matéria de repressão deve ser usada contenção e, por último, a dúvida beneficia o acusado.

O Pacto Internacional de Direitos Civis e Políticos de 1966 promulgado pelo Decreto $\mathrm{n}^{\circ}$ 592, de 06 de julho de 1992 preceitua em seu art.14, item 2, que "toda pessoa acusada de um delito terá direito a que se presuma sua inocência enquanto não for legalmente comprovada sua culpa" e as regras mínimas da Organização das Nações Unidas para a Administração da Justiça da Infância e da Juventude também conhecidas como as Regras de Beijing referente aos direitos dos jovens em seu item 7.1 estabelecem que:

Respeitar-se-ão as garantias processuais básicas em todas as etapas do processo, como a presunção de inocência, o direito de ser informado das acusações, o direito de não responder, o direito à assistência judiciária, o direito à presença dos pais ou tutores, o direito à confrontação com testemunhas e a interrogá-las e o direito de apelação ante uma autoridade superior. 
As Regras mínimas para a proteção dos jovens privados de liberdade da Organização das Nações Unidas, inciso III, item 17 sobre os "menores sob detenção ou que aguardam julgamento" que orientam no sentido de que:

Os menores que estão detidos preventivamente ou que aguardam julgamento (não julgados) presumem-se inocentes e serão tratados como tal. A detenção antes do julgamento deve ser evitada, na medida do possível, e limitada a circunstâncias excepcionais. Devem, por isso, ser feitos todos os esforços para se aplicarem medidas alternativas. No entanto, quando se recorrer à detenção preventiva, os tribunais de menores e os órgãos de investigação tratarão tais casos com a maior urgência, a fim de assegurar a mínima duração possível da detenção. Os detidos sem julgamento devem estar separados dos menores condenados.

Por último, as regras mínimas para o tratamento dos reclusos em seu art. 84.2 estabelecem que "os presos não julgados presumem-se inocentes e como tal devem ser tratados".

Por seu turno, a Carta dos Direitos Fundamentais da União Europeia (2000/C 364/01), proclamada em Nice, em 07 de dezembro de 2000 em seu art. 48.1 estabelece que "todo o imputado se presume inocente enquanto não tiver sido legalmente provada a sua culpa”.

Embora a Carta não possua valor jurídico vinculativo, reconheceu-se o seu valor político, cujos objetivos primordiais foram explicados em seu preâmbulo "é necessário, conferindo-lhes maior visibilidade por meio de uma Carta, reforçar a protecção dos direitos fundamentais, à luz da evolução da sociedade, do progresso social e da evolução científica e tecnológica". As referidas convenções obrigam os Estados signatários a assegurarem direitos aos seus cidadãos, considerados sujeitos de direito internacional convencional, que passaram a ter acesso direto às instâncias internacionais (Tribunal Europeu e o Tribunal Americano), quando se considerarem afetados no gozo dos direitos prescritos nas convenções às quais aderiram (VARALDA, 2007, p. 30-31).

\section{A CONVENÇÃO AMERICANA SOBRE DIREITOS HUMANOS}

A Convenção Americana sobre Direitos Humanos (CADH) foi assinada em 22 de novembro de 1969 na Conferência de San José, Costa Rica, mas o Brasil tomou parte apenas em 25 de novembro de 1992, estipulando como ressalva duas cláusulas facultativas: a do art. 45, 1º, que concede competência à Comissão Interamericana de Direitos Humanos para examinar queixas apresentadas por outros Estados acerca do descumprimento de alguma das obrigações impostas pelo pacto, e a constante no art. $62,1^{\circ}$, que estipula a jurisdição obrigatória da Corte Interamericana de Direitos Humanos para julgar os casos de violação denunciados. Todavia, pelo Decreto n ${ }^{\circ}$ 678, de 06 de novembro de 1992, a Convenção foi aceita no Brasil e, por meio de Decreto Legislativo de novembro de 1998, a cláusula de jurisdição obrigatória foi acatada (COMPARATO, 1999, p. 332), (CAMARGO, 2005, p. 296).

Segundo Gomes Filho (1991, p. 20), a CADH reproduziu as determinações listadas no Pacto Internacional sobre Direitos Civis e Políticos no que diz respeito aos direitos e garantias individuais, repetindo inclusive a previsão da presunção de inocência nos mesmos termos anteriores, como consta no seu art. 8.2 que "toda pessoa acusada de um delito terá direito a que se presuma sua inocência enquanto não se comprove legalmente sua culpa”.

Além da presunção de inocência, a CADH garante também o direito de recorrer, e por isso é citada na jurisprudência dos tribunais superiores brasileiros, como fundamento de revogação do art. 594 do Código de Processo Penal brasileiro que exigia a prisão como requisito para apelação. Todo esse quadro de legalização da presunção de inocência é retrato do franco 
reconhecimento de sua projeção internacional, a qual lhe concedeu tamanha magnitude dentro do Processo Penal, como signo da proteção do jus libertatis do indivíduo perante a máquina punitiva estatal (CAMARGO, 2005, p. 297-298).

No Brasil, o parágrafo $2^{\circ}$, do art. $5^{\circ}$, da Constituição Federal prescreve: "os direitos e garantia expressos nesta Constituição não excluem outros decorrentes do regime e dos princípios por ela adotados, ou dos tratados internacionais em que a República Federativa do Brasil seja parte.

Os tratados e convenções internacionais sobre direitos humanos foram, por fim, reconhecidos com status constitucional pelo art. $1^{\circ}, \S 3^{\circ}$, da $\mathrm{EC}^{\circ} 45$, publicada no Diário Oficial da União no dia 30 de dezembro de 2004, consolidando no ordenamento jurídico brasileiro um sistema misto, que combina regimes jurídicos diferenciados, um aplicável aos tratados de direitos humanos e um outro aplicável aos tratados tradicionais (PIOVESAN, 2005, p. 8).

Segundo Piovesan $\left(2005\right.$, p. 9), por força do $\S 2^{\circ}$, do art. $5^{\circ}$, da Constituição Federal brasileira, todos os tratados de direitos humanos são materialmente constitucionais, o que afasta $\mathrm{o}$ equivocado entendimento de que os tratados de direitos humanos ratificados antes da introdução do $\S 3^{\circ}$, do art. $5^{\circ}$, da Constituição pela EC no 45/2004 seriam recepcionados como lei federal, diante da falta do quórum qualificado de três quintos prescritos no referido parágrafo.

A autora aponta que o $\S 3^{\circ}$, do art. $5^{\circ}$ veio apenas reconhecer de modo expresso a natureza materialmente constitucional dos tratados de direitos humanos, já que "não seria razoável sustentar que os tratados de direitos humanos já ratificados fossem recepcionados como lei federal, enquanto que os demais adquirissem hierarquia constitucional exclusivamente em virtude do quórum de aprovação."

O avanço democrático brasileiro trouxe o compromisso ao legislador constituinte de 1988 em afirmar a presunção de inocência já consagrada em textos internacionais de direitos humanos. A par disso, estatuiu-se no art. $5^{\circ}$, inciso LVII, da Constituição Federal brasileira como princípio basilar do Processo Penal, dentro do capítulo referente aos direitos e garantias individuais, nos seguintes termos: "Ninguém será considerado culpado até o trânsito em julgado de sentença penal condenatória". Nota-se que a Constituição Federal não fez referência expressa ao termo "presunção de inocência" prosperando a opção doutrinária e jurisprudencial ao modelo que privilegia o jus libertatis frente ao jus puniendi, garantindo ao indivíduo um significado amplo da presunção de inocência (VARALDA, 2007, p. 44-46).

O significado amplo do preceito tornou-se inquestionável com a possibilidade do reconhecimento de status constitucional do art. $8^{\circ}$, inciso I, da Convenção Americana sobre Direitos Humanos pelo art. $1^{\circ}, \S 3^{\circ}$, da $\mathrm{EC} \mathrm{n}^{\circ} 45$, publicada no DOU, no dia 30 de dezembro de 2004, já que sua redação, conjugada com os ditames do art. 5º inciso LVII, da Constituição Federal, completam-se, expressando dois aspectos fundamentais da garantia (regra probatória e regra de tratamento). Vale dizer que, no Brasil, a presunção de inocência está presente não apenas perante as garantias constitucionais do processo penal, mas também em qualquer fase administrativa ou jurisdicional, cuja decisão implique em caráter sancionador ou limitador de direitos. Até o trânsito em julgado de sentença condenatória, o réu tem o direito público subjetivo de não ser submetido ao estado de condenado (VARALDA, 2007, p. 47-48).

A presunção de inocência constitui, assim, no Estado de Direito, o pressuposto e o parâmetro de todas as atividades estatais concernentes à repressão criminal (GOMES FILHO, 1992, p. 19), ou melhor, o Estado de Direito é o Estado de Direito racional, isto é, o Estado que realiza os princípios da razão na e para a vida em comum dos homens, tal e como estavam formulados na tradição da teoria do direito racional (BÖCKENFÖRD, 2000, p. 19).

\section{A NATUREZA JURÍdiCA DA PRESUNÇÃo DE INOCÊNCIA (OU DE NÃO CULPABILIDADE)}


A natureza jurídica da presunção de inocência é bastante controvertida. Um setor doutrinário considera que se trata de uma praesumptiones iuris tantum, isto é, do ponto de vista normativa a presunção deve ser entendida como norma jurídica que pode ser afastada por "prova contrária efetiva". A presunção de inocência se desconecta da verdade e se encaminha à proteção de outros valores. Não parece que haja regra de experiência que leve o legislador a pensar que, em geral, os acusados são inocentes. A presunção de inocência não está fundada sobre uma probabilidade empírica de condenação, mas constitui regra de dever ser, que conduz o legislador a estabelecer uma garantia processual dirigida a proteger valores ideológicos ou políticos e técnicos: o valor ideológico é a garantia da posição de liberdade do acusado em face do interesse coletivo à repressão penal, enquanto o valor técnico ou instrumental se plasma na segurança jurídica ao indicar ao juiz a regra de julgamento a fim de evitar que possa produzir um resultado indesejável (a condenação de inocentes), (GOMES FILHO, 2006, p. 319), (SANGUINÉ, 2014, p. 190).

Outro setor doutrinário considera que não se trata de uma autêntica presunção em sentido técnico-processual, pois lhe faltam praticamente todos os elementos, nem de uma regra de ônus da prova, mas sim um direito fundamental que serve como verdadeiro princípio informador irrenunciável de todas as fases do processo penal em matéria de valoração da prova e de adoção de medidas cautelares restritivas de direitos constitucionais, incluído entre as chamadas verdades interinas ou provisórias (de caráter probatório), destinada a proteger o acusado e afastar o juiz (bem como os poderes públicos e hoje os meios de comunicação) de um prejulgamento social de culpabilidade baseado na mera suspeita. Desta maneira, a presunção de inocência opera em todos os casos em que a culpabilidade do acusado permanece na incerteza, substituindo esta pela certeza da inocência do acusado. Portanto, a presunção de inocência funciona no processo penal como se fosse uma presunção iuris tantum, que produz seus efeitos até que seja deslocada por uma prova em sentido contrário da certeza jurídica da culpabilidade (SANGUINÉ, 2014, p. 190-191).

A presunção de inocência como regra de tratamento do imputado produz efeitos também em favor do cidadão suspeito desde a fase investigatória ou instrutória em relação à prisão provisória, precisamente quando a garantia é mais necessária contra juízos apressados que podem levar à identificação do simples suspeito com o culpado, bem como durante todo o desenvolvimento do processo penal (GOMES FILHO, 2006, 126).

Entretanto, na medida em que se considera compatível a prisão provisória com a presunção de inocência e com o princípio nulla poena sine praevio iudicio, torna-se questão primordial estabelecer quais os critérios que regerão o juízo sobre normas cautelares e, sobretudo, conhecer qual o nexo que subsiste com o julgamento final que anuncia a aplicação das normas penais. A proibição de equiparar o tratamento processual do imputado ao culpado implica a impossibilidade de expressar uma valoração antecipada de responsabilidade e impede, portanto, que a privação da liberdade ante iudicatum possa encontrar seu fundamento justificativo, ainda que provisório, em apreciações sobre o mérito da imputação. Afirmar que o cidadão se presume inocente implica a proibição de infligir-lhe uma "pena pela suspeita" (SANGUINÉ, 2014, p. 192).

\section{OS DIREITOS FUNDAMENTAIS COMO DIREITOS RESTRINGÍVEIS}

Para Sanguiné (2014, p. 49), existe praticamente um consenso na doutrina e na jurisprudência constitucional acerca do caráter limitado - não absoluto - dos direitos constitucionais. Como nenhuma ordem jurídica pode proteger os direitos fundamentais de maneira ilimitada, predomina a ideia de que estes não são absolutos, isto é, blindados contra qualquer tipo de restrição na sua esfera subjetiva e objetiva. Portanto, os direitos fundamentais estão sujeitos a restrições e podem ser restringíveis ou limitados. 
Isso ocorre porque os direitos fundamentais estão reconhecidos normalmente em normas constitucionais com forma de princípios: se trata de mandados de otimização abertos e indeterminados, que, ao contrário das regras - que emitem comandos definitivos, com base no "tudo ou nada", podem ser cumpridas ou não - estabelecem obrigações de proteção ou promoção que são cumpridas em diferentes graus, ou seja, na maior medida possível, dentro das possibilidades jurídicas e reais existentes. Portanto, os princípios são mandados de otimização, que se caracterizam porque podem cumprir-se em diferente grau e que a medida devida de seu cumprimento não depende somente das possibilidades reais, mas também das jurídicas. O âmbito das possibilidades jurídicas se determina pelos princípios e regras opostos, o que exige sejam ponderados com outros mandados similares (ALEXY, 2007, p. 67 e ss.), (BARROSO, 2009, p. 207 e ss.), (SANGUINÉ, 2014, p. 50).

A discussão sobre a possibilidade de restringir os direitos fundamentais conduz ao debate sobre as chamadas teorias das restrições: a teoria externa e a teoria interna dos limites aos direitos fundamentais.

Para a "teoria externa" (ou teoria das restrições aos direitos resultantes dos direitos dos outros ou impostas por lei), há dois objetos jurídicos diferentes: o primeiro objeto é o direito prima facie ou direito não limitado; o segundo a restrição desse direito. Como resultado da restrição se obtém o direito definitivo limitado ou restringido. Sempre que um direito existe, há uma norma que garante esse direito. Depois, estabelecem-se normas restritivas destes direitos. $\mathrm{O}$ esquema básico deste pensamento consiste na regra do direito e a exceção da restrição. Portanto, os direitos se apresentam primordial ou exclusivamente como direitos restringidos. Por isso, não existe nenhuma relação necessária entre o conceito de direito e o de restrição. Esta relação somente se cria por meio da necessidade, externa ao direito, de fazer compatíveis entre si os direitos de diferentes indivíduos, assim como os direitos individuais e os bens coletivos. $\mathrm{O}$ exame de um direito limitado se realiza necessariamente em duas etapas. Na primeira se pergunta se a consequência jurídica buscada forma parte do conteúdo do direito prima facie. Se isso é assim, em uma segunda etapa se examina se o direito prima facie foi limitado legitimamente no caso concreto, de tal forma que já não se tenha um direito definitivo. A teoria dos direitos restringíveis ou teoria externa está assim apta para reconstruir a colisão entre objetos normativos, em especial, a colisão entre direitos e bens coletivos (ALEXY, 2007, p. 240), (SANGUINÉ, 2014, p. 50-51), (BOROWSKI, 2003, p. 66-68), (SARLET, 1998, p. 389).

Por sua parte, segundo a "teoria interna" dos direitos (ou teoria dos limites imanentes), existe desde o início o direito com seu conteúdo determinado de antemão; ele já nasce com seus limites. Toda posição jurídica que exceda dito direito predeterminado não existe. Desde este ponto de vista, há somente um objeto normativo: o direito com seus limites concretos. $\mathrm{O}$ conceito de restrição é substituído pelo de "limites imanentes" ou fronteiras implícitas apriorísticas. As dúvidas acerca dos limites do direito não são dúvidas sobre se o direito deve ou não ser limitado, mas a respeito de qual é seu conteúdo. Se o direito, em sua acepção de direito não limitável, tem seu alcance definido de antemão, sua restrição se torna desnecessária e impossível (ALEXY , 2007, p. 240-241), (SANGUINÉ, 2014, p. 51), (BOROWSKI, 2003, p. 68-69), (SARLET, 1998, p. 388).

Portanto, cabe falar de "restrições aos direitos fundamentais" no sentido de que o que se pode restringir são os bens protegidos pelos direitos fundamentais (as liberdades/as situações/as posições de direito ordinário) e as posições prima facie conferidas pelos princípios de direito fundamental. Os princípios de direito fundamental exigem uma proteção o mais ampla possível dos bens protegidos, ou seja, uma proteção o mais ampla possível da liberdade geral de ação, da integridade física etc. Por isso, a restrição de um bem protegido é sempre a restrição de uma posição prima facie conferida pelo princípio de direito fundamental. Destarte, as restrições aos direitos fundamentais são normas que restringem as posições prima facie de direito fundamental. Porém, as normas podem ser restrições aos direitos fundamentais somente se são constitucionais. 
Se não o é, sua criação pode ter o caráter de uma intervenção, porém não de uma restrição. Os direitos fundamentais são sempre ou normas de categoria constitucional ou normas de categoria inferior à da Constituição, que normas de categoria constitucional autorizam a impor restrições (ALEXY, 2007, p. 243-244 e 248-249), (SANGUINÉ, 2014, p. 53).

Ademais, não somente as regras, mas também os princípios formam parte das normas que podem ser restrições aos direitos fundamentais nos casos em que constituam uma razão para que, em lugar de uma liberdade ou de um direito fundamental prima facie, apareça uma não liberdade definitiva ou um não direito definitivo de igual conteúdo. Quando se afirma que os direitos fundamentais de terceiros que entrem em colisão e outros valores jurídicos de hierarquia constitucional podem limitar direitos fundamentais, se faz referência às restrições dos direitos fundamentais que têm o caráter de princípios. (ALEXY, 2007, p. 246-247), (SANGUINÉ, 2014, p. 53).

\section{OS LIMITES DOS DIREITOS FUNDAMENTAIS}

Em relação às espécies de limitações, há consenso no sentido de que os direitos fundamentais podem ser restringidos: a) tanto por expressa disposição constitucional como por b) norma legal promulgada com fundamento na Constituição, aqui se incluindo as restrições por força de colisões entre direitos fundamentais, mesmo inexistindo limitação ou autorização expressa assegurando a possibilidade de restrição pelo legislador. Em qualquer caso, uma restrição de direito fundamental exige, seja, direta (estabelecida pela própria Constituição), seja indiretamente (estabelecida por lei - reserva legal simples ou qualificada), um fundamento constitucional (SARLET, 1998, p. 391-392 e ss.).

Para a restrição válida de um direito fundamental, não basta que o legislador vise à salvaguarda de um interesse geral, mas é necessário, além disso, que esse interesse seja direta ou indiretamente relacionável a um valor ou bem jurídico constitucionalmente garantido. Trata-se da "doutrina dos limites imanentes", expressada por fórmulas como "nenhum direito é absoluto" ou "todos os direitos são limitados", que sustenta que, independentemente de que o correspondente enunciado constitucional preveja ou não a possibilidade de restrição legislativa, todo direito fundamental fica limitado pela necessidade de fazê-lo compatível com os demais direitos e bens jurídicos protegidos pela Constituição; o que conduz a expor toda intervenção legislativa nesta matéria como a busca de uma solução à colisão entre direitos e bens jurídicos de status constitucional e, portanto, como um exercício de ponderação (DÍEZ-PICAZO, 2005, p. 117), (SANGUINÉ, 2014, p. 56).

Como complemento à questão da delimitação dos direitos fundamentais, alguns critérios da hermenêutica constitucional concernente aos direitos fundamentais devem ser levados em conta nesse processo de delimitação: a) o "princípio da unidade da Constituição" - segundo o qual as normas constitucionais devem ser aplicadas não como normas isoladas, mas como preceitos integrados num sistema unitário de regras e princípios instituídos pela própria Constituição; b) o princípio da "concordância prática" ou "harmonização" ou "otimização": a ambos os direitos devem ser traçados limites no caso concreto, para que ambos possam chegar à eficácia ótima, evitando que um seja realizado à custa do outro, ou a aniquilação do direito não prevalente. A concreta conciliação dos preceitos constitucionais permite a restrição necessária e proporcional do exercício dos direitos, mas não pode implicar o sacrifício ou supressão unilateral de um deles em benefício total do outro. Antes, exige uma ponderação em que ambos sejam preservados na maior medida possível e sejam sacrificados na menor medida possível (HESSE, 1998, p. 66-67), (SANGUINÉ, 2014, p. 59-60), (MORAES, 2007, p. 27).

Também pode ser útil o princípio da interpretação conforme a Constituição, que abriga, simultaneamente, uma técnica de interpretação e um mecanismo de controle de constitucionalidade. Como técnica de interpretação, o princípio impõe a juízes e tribunais que 
interpretem a legislação ordinária de modo a realizar, de maneira mais adequada, os valores e fins constitucionais, escolhendo, entre interpretações possíveis, a que tem mais afinidade com a Constituição. Como mecanismo de controle de constitucionalidade, a interpretação conforme a Constituição permite que o intérprete, sobretudo o tribunal constitucional, preserve a validade de uma lei que seria inconstitucional. Nessa hipótese, o tribunal, simultaneamente, infirma uma das interpretações possíveis, declarando-a inconstitucional, e afirma outra, que compatibiliza a norma com a Constituição. Trata-se de uma interpretação corretiva que importa na declaração de inconstitucionalidade sem redução de texto. (BARROSO, 2009, p. 301), (SANGUINÉ, 2014, p. 60-61).

\section{A DERROTABILIDADE (OU SUPERABILIDADE) DAS NORMAS DE DIREITOS FUNDAMENTAIS}

Dimoulis; Martins (2009, p. 47) e Souza (2011, p. 25) prelecionam que "a posição dos direitos fundamentais no sistema jurídico define-se com base na fundamentalidade formal”, o que significa que um direito é fundamental se, e somente se, for garantido mediante normas que tenham a força jurídica própria da supremacia constitucional. Normas de direitos fundamentais, portanto, são as normas constitucionais que prevêem tais direitos, verdadeiras emanações da dignidade da pessoa humana.

A partir da distinção entre regras e princípios, os catálogos de direitos fundamentais podem ser considerados de três formas distintas. De acordo com o chamado modelo puro de regras, todos os direitos fundamentais são tutelados por meio de normas que apresentam a natureza de regras, aplicáveis de modo absoluto e incondicional, sem recurso a ponderação ou sopesamento. Todos os direitos fundamentais são tutelados por normas que apresentam a natureza de princípios, aplicáveis por ponderação ou balanceamento, em detrimento da vinculação e da normatividade do texto constitucional. Dessa forma, os direitos fundamentais são tutelados por normas que apresentam natureza de regras e por normas que apresentam natureza de princípios, conciliando-se a taxatividade das regras e a flexibilidade dos princípios (ALEXY, 2008, p. 135-143), (SOUZA, 2011, p. 26).

Dessa forma, o modelo de regras e princípios ou o modelo da teoria dos princípios é o mais adequado para orientar a interpretação do sistema de direitos fundamentais estatuído na Constituição Federal de 1988 uma vez que a positivação dos direitos seguiu um modelo híbrido que compreende princípios e regras, porquanto os dispositivos de direito fundamental ostentam densidades variadas (PEREIRA, 2006, p. 126).

Ressalta que "todos os direitos fundamentais são restringíveis e todos os direitos fundamentais são regulamentáveis". Eles podem ser relativizados em atenção a outros direitos fundamentais ou a interesses públicos constitucionalmente protegidos (SILVA V., 2010, p. 246).

Exatamente a relatividade dos direitos fundamentais faz com que as normas que os tutelem possam ser derrotadas. O caráter não absoluto dos direitos fundamentais evidencia, em especial, que as normas que os protegem são informadas pela ideia de derrotabilidade. Diante de um caso concreto, em face da argumentação desenvolvida, uma norma que tutela determinado direito fundamental pode ser superada em razão da necessidade de aplicação de uma norma que protege outro direito fundamental ou de uma norma constitucional que consagra um interesse público. Além do mais, em razão da força expansiva dos direitos fundamentais, as normas que os protegem são também invocadas como fundamento para excepcionar, superar ou derrotar outras normas constitucionais (SOUZA, 2011, p. 27-29).

A admissão da ideia da derrotabilidade das normas de direitos fundamentais, contudo, não pode conduzir a um enfraquecimento da tutela desses direitos. Uma norma de direito fundamental somente pode ser superada ou excepcionada mediante argumentação racional baseada em rigorosa justificação externa ou de segunda ordem. A derrotabilidade de normas de 
direitos fundamentais relaciona-se estreitamente com a colisão ou a restrição de tais direitos. Por isso, a superação de normas de direitos fundamentais deve ser racionalmente informada pelo princípio da proporcionalidade e seus elementos constitutivos: adequação, necessidade e proporcionalidade em sentido estrito (SOUZA, 2011, p. 30).

Portanto, é possível uma decisão judicial individualizada e específica, superando a norma regulatória, para homenagear os valores existenciais do sistema jurídico (e que, em última análise, são perseguidos, com toda convicção, pelas próprias normas-regras aludidas). É como se a norma-regra contivesse uma cláusula implícita em seu âmago, estabelecendo a sua obrigatória aplicação, "a menos que" uma situação extraordinária se concretizasse (HART, 1986).

Com isso, será possível fazer justiça no caso concreto, através do levantamento episódico e concreto da regulamentação decorrente de uma norma-regra (afastamento pontual da norma de regência), buscando uma fundamentação condizente com um ideal de justiça social (CF, art. $3^{\circ}$ ), (BRASIL, 1988).

Até mesmo porque, cuidadosamente analisando, excepcionar a aplicação da norma-regra em um determinado caso em exame pode se justificar em nome dos próprios valores perseguidos pelas regras - que serão episodicamente superadas, permitindo uma decisão paradigmática e referencial para os casos símiles (FARIAS, 2015, p. 32).

\section{O PRINCÍPIO DA PRESUNÇÃO DE INOCÊNCIA (OU DA NÃO CULPABILIDADE) NA INTERPRETAÇÃO DO STF: O CASO DO JULGAMENTO DO HC 126.292}

Em decisão durante o julgamento do HC 126.292/SP, de relatoria do Ministro Teori Zavascki, o Supremo Tribunal Federal brasileiro modificou sua jurisprudência e firmou o entendimento no sentido de permitir a execução provisória da pena após a confirmação de condenações criminais em segunda instância. A decisão indica mudança no entendimento do STF, que desde 2009, no julgamento do HC 84078, condicionava a execução da pena ao trânsito em julgado da condenação, mas ressalvava a possibilidade de prisão preventiva.

A decisão se deu por maioria de sete a quatro, sendo vencidos os Ministros Rosa Weber, Marco Aurélio, Celso de Mello e Ricardo Lewandowski que votaram pela manutenção da jurisprudência do Tribunal que exige o trânsito em julgado para cumprimento de pena e concluíram pela concessão do habeas corpus. O Relator Ministro Teori Zavascki votou pelo indeferimento do pleito, acompanhado pelos Ministros Edson Fachin, Luís Roberto Barroso, Luiz Fux, Dias Tóffoli, Cármen Lúcia e Gilmar Mendes.

Em seu voto, o Relator destacou, em outras palavras o tema relacionado com a execução provisória de sentenças penais condenatórias envolve reflexão sobre:

a) o alcance do princípio da presunção de inocência aliado à;

b) busca de um necessário equilíbrio entre esse princípio e a efetividade da função jurisdicional penal, que deve atender a valores caros não apenas aos acusados, mas também à sociedade, diante da realidade de nosso intricado e complexo sistema de justiça criminal.

Partindo uma interpretação histórica, o voto do Relator Teori Zavascki afirma que o princípio da presunção de inocência (ou de não culpabilidade) se encontra positivado no inciso LVII do art. $5^{\circ}$ da Constituição Federal de 1988. Tal princípio ganhou destaque no ordenamento jurídico nacional no período de vigência da Constituição de 1946, com a adesão do país à Declaração Universal dos Direitos do Homem de 1948, cujo art. 11.1 estabelece:

Toda pessoa acusada de delito tem direito a que se presuma sua inocência, enquanto não se prova sua culpabilidade, de acordo com a lei e em processo público no qual se assegurem todas as garantias necessárias para sua defesa. 
O reconhecimento desse verdadeiro postulado civilizatório teve reflexos importantes na formulação das supervenientes normas processuais, especialmente das que vieram a tratar da produção das provas, da distribuição do ônus probatório, da legitimidade dos meios empregados para comprovar a materialidade e a autoria dos delitos. A implementação da nova ideologia no âmbito nacional, agregou ao processo penal brasileiro, parâmetros para a efetivação de modelo de justiça criminal racional, democrático e de cunha garantista, como o do devido processo legal, da ampla defesa, do contraditório, do juiz natural, da inadmissibilidade de obtenção de provas por meios ilícitos, da não auto-incriminação (nemo tenetur se detegere), com todos os seus desdobramentos de ordem prática, como o direito de igualdade entre as partes, o direito à defesa técnica plena e efetiva, o direito de presença, o direito ao silêncio, o direito ao prévio conhecimento da acusação e das provas produzidas, o da possibilidade de contraditá-las, com o consequente reconhecimento da ilegitimidade da condenação que não esteja devidamente fundamentada e assentada em provas produzidas sob o crivo do contraditório (BRASIL, 1946), (BRASIL, 1988).

Realmente, antes de prolatada a sentença penal há de se manter reservas de dúvida acerca do comportamento contrário à ordem jurídica, o que leva a atribuir ao acusado, para todos os efeitos - mas, sobretudo, no que se refere ao ônus da prova da incriminação -, a presunção de inocência. A eventual condenação representa, por certo, um juízo de culpabilidade, que deve decorrer da logicidade extraída dos elementos de prova produzidos em regime de contraditório no curso da ação penal. Para o sentenciante de primeiro grau, fica superada a presunção de inocência por um juízo de culpa - pressuposto inafastável para condenação -, embora não definitivo, já que sujeito, se houver recurso, à revisão por Tribunal de hierarquia imediatamente superior. É nesse juízo de apelação que, de ordinário, fica definitivamente exaurido o exame sobre os fatos e provas da causa, como a fixação, se for o caso, da responsabilidade penal do acusado. É ali que se concretiza, em seu sentido genuíno, o duplo grau de jurisdição, destinado ao reexame de decisão judicial em sua inteireza, mediante ampla devolutividade da matéria deduzida na ação penal, tenha ela sido apreciada ou não pelo juízo a quo. Ao réu fica assegurado o direito de acesso, em liberdade, a esse juízo de segundo grau, respeitadas as prisões cautelares porventura decretadas.

O Relator afirma ainda que ressalvada a estreita via da revisão criminal, é, portanto, no âmbito das instâncias ordinárias que se exaure a possibilidade de exame de fatos e provas e, sob esse aspecto, a própria fixação da responsabilidade criminal do acusado. É dizer: os recursos de natureza extraordinária não configuram desdobramentos do duplo grau de jurisdição, porquanto não são recursos de ampla devolutividade, já que não se prestam ao debate da matéria fática probatória. Noutras palavras, com o julgamento implementado pelo Tribunal de apelação, ocorre espécie de preclusão da matéria envolvendo os fatos da causa. Os recursos cabíveis para instâncias extraordinárias do STJ e do STF - recurso especial e extraordinário - têm âmbito de cognição estrito à matéria de direito. Nessas circunstâncias, tendo havido, em segundo grau, um juízo de incriminação do acusado, fundado em fatos e provas insuscetíveis de reexame pela instância extraordinária, parece inteiramente justificável a relativização e até mesmo a própria inversão, para o caso concreto, do princípio da presunção de inocência até então observado. Faz sentido, portanto, negar efeito suspensivo aos recursos extraordinários, como o fazem o art. 637 do Código de Processo Penal e o art. 27, §2º , da Lei 8.038/1990. (BRASIL, 1941), (BRASIL, 1990).

O estabelecimento desses limites ao princípio da presunção de inocência também tem merecido a atenção do Ministro Gilmar Mendes, que, a propósito escreveu:

No que se refere ao princípio da presunção de inocência (ou de não culpabilidade), seu núcleo essencial impõe o ônus da prova do crime e sua autoria à acusação. Sob esse aspecto, não há maiores dúvidas de que estamos falando de um direito fundamental processual, de âmbito negativo. 
Para além disso, a garantia impede, de uma forma geral, o tratamento do réu como culpado até o trânsito em julgado da sentença. No entanto, a definição do que vem a ser tratar como culpado depende de intermediação do legislador.

Ou seja, a norma afirma que ninguém será considerado culpado até o trânsito em julgado da condenação, mas está longe de precisar o que vem a ser considerar alguém culpado.

O que se tem é, por um lado, a importância de preservar o imputado contra juízos precipitados acerca de sua responsabilidade. Por outro, uma dificuldade de compatibilizar o respeito ao acusado com a progressiva demonstração de sua culpa.

Disso se deflui que o espaço de conformação do legislador é lato. A cláusula não obsta que a lei regulamente os procedimentos, tratando o implicado de forma progressivamente mais gravosa, conforme a imputação evolui. Por exemplo, para impor uma busca domiciliar, bastam fundadas razões - art. $240, \S 1^{\circ}$, do CPP. Para tornar implicado o réu, já são necessários a prova da materialidade e indícios da autoria (art. 395, III, do CPP). Para condená-lo é imperiosa a prova além de dúvida razoável.

Como observado por Eduardo Espínola Filho, a presunção de inocência é vária, segundo os indivíduos sujeitos passivos do processo, as contingências da prova e o estado da causa.

Ou seja, é natural à presunção de não culpabilidade evoluir de acordo com o estágio de procedimento. Desde que não se atinja o núcleo fundamental, o tratamento progressivamente mais gravoso é aceitável (...)

Esgotadas as instâncias ordinárias com a condenação à pena privativa de liberdade não substituída, tem-se uma declaração, com considerável força de que o réu é culpado e a sua prisão necessária.

Nesse estágio, é compatível com a presunção de não culpabilidade determinar o cumprimento das penas, ainda que pendentes recursos.

Do mesmo modo, ainda para o Ministro Gilmar Mendes os recursos extraordinários têm sua fundamentação vinculada a questões federais (recurso especial) e constitucionais (recurso extraordinário) e, por força da lei (art. 637 do CPP) e mesmo da tradição, não têm efeito suspensivo. A análise das questões federais e constitucionais em recursos extraordinários, ainda que decorra da provocação da parte recorrente, serve preponderantemente não ao interesse do postulante, mas ao interesse coletivo no desenvolvimento e aperfeiçoamento da jurisprudência. Esgotadas as instâncias ordinárias com a condenação à pena privativa de liberdade não substituída, tem-se uma declaração, com considerável, força de que o réu é culpado e a sua prisão necessária. Nesse estágio, é compatível com a presunção de não culpabilidade determinar o cumprimento das penas, ainda que pendentes recursos (BRASIL, 1941).

Por seu turno, o Rel. Teori Zavascki defendeu o entendimento de que a execução da pena na pendência de recursos de natureza extraordinária não compromete o núcleo essencial do pressuposto da presunção de inocência (ou da não culpabilidade), na medida em que o processo ordinário criminal, observados os direitos e as garantias a ele inerentes, bem como respeitadas as regras probatórias e o modelo acusatório atual. Não é incompatível com a garantia constitucional autorizar, a partir daí, ainda que cabíveis ou pendentes de julgamento de recursos extraordinários, a produção dos efeitos próprios da responsabilização criminal reconhecida pelas instâncias ordinárias.

Há também o exemplo da Lei Complementar no 135/2010 (lei da ficha limpa), que, em seu art. $1^{\circ}$, I, expressamente consagra como causa de inelegibilidade a existência de sentença condenatória por crimes nela relacionados quando proferidas por órgão colegiado. É dizer, a presunção de inocência não impede que, mesmo antes do trânsito em julgado, o acórdão condenatório produza efeitos contra o acusado (BRASIL, 2010). 
Nesse contexto, a Lei Complementar $n^{\circ}$ 135/2010 trouxe novos dispositivos e alterou outros previstos na Lei Complementar $n^{\circ}$ 64/1990, entre os quais, o art.15 da Lei Complementar no 64/90 que afirma que a restrição à capacidade eleitoral passiva, a partir da decisão do órgão colegiado, não fere o princípio da presunção de inocência (ou da não culpabilidade), assentado que a decisão que veicular inelegibilidade não mais será executada apenas após o esgotamento dos prazos recursais, ou seja, será executada independentemente do trânsito em julgado da decisão, com a publicação da decisão proferida por órgão colegiado da Justiça Eleitoral (TRE ou TSE), (DUARTE, 2013, p. 19).

Para Zílio (2012, p. 151), a inelegibilidade revela "o impedimento ou restrição à capacidade eleitoral passiva", capacidade de ser votado, e tem base constitucional, art.14 $\S 4^{\circ}$ a $8^{\circ}$ da CF e também decorrente de Lei Complementar (art.14, $\S 9^{\circ}$, da CF e Lei Complementar $n^{\circ}$ 64/90 alterada pela Lei Complementar nº 135/2010.

Equivale a dizer, "a inelegibilidade é um critério jurídico-político objetivo (abstrato) previsto em lei para definir o perfil esperado dos exercestes de mandato eletivo" e tem por pressuposto uma atuação preventiva do Estado, de modo a preservar o bem jurídico tutelado, qual seja o mandato político (REIS, 2012).

A norma constitucional do art.14, $\S 9^{\circ}$, enuncia o princípio da proteção que visa a afastar os pretendentes a mandato eletivo que representem risco para a administração, e, por conseguinte, aos valores da moralidade e probidade administrativas. A Lei Complementar $n^{\circ}$. 64/90 alterada pela Lei Complementar no 135/2010 ou Lei da Ficha Limpa, como ficou conhecida, determina casos de inelegibilidades e prazos de cessação, prevendo ocasião para impugnação ao registro de candidaturas e os atos processuais a serem adotados nessa ocasião. (DUARTE, 2013, p. 18).

Para o Min. Gilmar Mendes, o que se quer dizer é que a própria credibilidade das instituições em geral, e da justiça em particular, fica abalada se o condenado por crime grave não é chamado a cumprir sua pena em tempo razoável. Além disso, a condenação pelo Tribunal atesta os fatos com soberania. Se foi imposta, após o julgamento colegiado, uma pena privativa de liberdade em regime inicial fechado, é porque houve um fato grave, atestado quando sua existência e autoria, pelas instâncias ordinárias.

Assim, esgotadas as vias ordinárias, com imposição de pena privativa de liberdade em regime inicial fechado, o cumprimento da pena se justifica para a garantia da ordem pública. Em suma, seja porque a presunção de inocência é um direito com âmbito de proteção normativo, passível de conformação pela legislação ordinária; seja porque a garantia da ordem pública autoriza a prisão, em casos graves, após o esgotamento das vias ordinárias, conclui o Min. Gilmar Mendes.

No voto do Relator ainda se extrai que os recursos de natureza extraordinária não têm por finalidade específica examinar a justiça ou injustiça de sentenças em casos concretos. Destinam-se, precipuamente, à preservação da higidez do sistema normativo. Isso ficou mais uma vez evidenciado, no que se refere ao recurso extraordinário, com a edição da EC no 45/2004, ao inserir como requisito de admissibilidade desse recurso a existência de repercussão geral da matéria a ser julgada, impondo ao recorrente, assim, o ônus de demonstrar a relevância jurídica, política, social ou econômica da questão controvertida. Vale dizer, o STF somente está autorizado a conhecer daqueles recursos que tratem de questões constitucionais que transcendam o interesse subjetivo da parte, sendo irrelevante, para esse efeito, as circunstâncias do caso concreto. E, mesmo diante das restritas hipóteses de admissibilidade dos recursos extraordinários, tem se mostrado infrequentes as hipóteses de êxito do recorrente. Afinal, os julgamentos realizados pelos Tribunais Superiores não se vocacionam a permear a discussão acerca da culpa, e, por isso, apenas excepcionalmente teriam, sob o aspecto fático, aptidão para modificar a situação do sentenciado.

É relevante anotar que o último marco interruptivo do prazo prescricional antes do início do cumprimento da pena é a publicação da sentença ou do acórdão recorríveis (art. 117, IV, do 
CP). Isso significa que os apelos extremos, além de não serem vocacionados à resolução de questões relacionadas a fatos e provas, não acarretam a interrupção da contagem do prazo prescricional. Assim, ao invés de constituir um instrumento de garantia da presunção de inocência (ou de não culpabilidade) do apenado, acabam representando um mecanismo inibidor da efetividade da jurisdição penal.

Por seu turno, Ministro Luís Roberto Barroso em seu voto acrescentou algumas considerações a mais no sentido de esclarece que a condenação de primeiro grau, mantida em recurso de apelação, inverte a presunção de inocência. Qualquer acusado em processo criminal tem direito a dois graus de jurisdição. Esse é o seu devido processo legal. A partir daí, a presunção de não culpabilidade estará desfeita. Além disso, o recurso extraordinário não se destina a investigar o acerto ou desacerto da decisão, nem a reestudar os fatos, nem a reapreciar a prova. Ele se destina a discutir tão somente alguma questão de direito, de direito constitucional quando seja perante o Supremo Tribunal Federal, e de direito infraconstitucional quando seja perante o Superior Tribunal de Justiça. Mas a materialidade e a autoria já foram demonstradas no primeiro e no segundo grau de jurisdição. Ademais, a impossibilidade de execução imediata de uma decisão condenatória de segundo grau fomenta a interposição sucessiva de recursos protelatórios. E isso, evidentemente, não é alguma coisa que se queira estimular.

Do ponto de vista dogmático, nos termos da Constituição Federal de 1988, a interposição de recurso especial e de recurso extraordinário pressupõe que a causa já tenha sido decidida. É o que está escrito no art. 102 "compete ao Supremo a guarda da Constituição, cabendo-lhe julgar mediante recurso extraordinário as causas decididas em única ou última instância". E o mesmo é asseverado em relação ao recurso especial no Superior Tribunal de Justiça. Pois bem, causa decidida é aquela que já foi definitivamente resolvida pelo Poder Judiciário à luz dos fatos e das provas de materialidade e de autoria.

Acrescenta ainda que, no Brasil, o Juiz de primeiro grau e o Tribunal de Justiça passaram a ser instâncias de passagem, porque os processos em sede recursal são encaminhados para o Superior Tribunal de Justiça e depois para o Supremo Tribunal Federal, numa sucessão infindável de instâncias. Reitera que o devido processo legal se realiza substancialmente em dois graus de jurisdição. Daí porque com essa nova orientação se restabelecerá a importância e o prestígio da decisão de primeiro grau e, sobretudo, do acórdão do Tribunal de Justiça. Em suma, o que se propõe é tornar o sistema minimamente eficiente e diminuir o grau de impunidade.

E mais que isso, o grau de seletividade do sistema punitivo brasileiro, porque quem tem condições de manter advogado para interpor um recurso descabido atrás de outro não são os pobres, que hoje superlotam as prisões brasileiras. Ninguém deve ser punido por ser rico. Ricos e pobres têm os mesmos direitos. Porém, o sistema é dramaticamente seletivo, porque as pessoas acima de um determinado patamar, mesmo que condenadas, não cumprem a pena durante a sua sobrevida, porque o sistema permite que se procrastine a execução por mais de vinte anos, conclui o Ministro Luís Roberto Barroso.

\section{A POSIÇÃo CONTRÁRIA do MINISTRO CELSO DE MELLO NO JULGAMENTO DA MEDIDA CAUTELAR NO HC 135.100/MG}

O Relator Ministro Celso de Mello, no julgamento da Medida Cautelar no HC 135.100/MG impetrado afastou a força vinculante da decisão proferida no julgamento do HC 126.292/SP, do colegiado, em que se entendeu possível "a execução provisória de acórdão penal condenatório proferido em grau de apelação, ainda que sujeito a recurso especial ou extraordinário", pois tal decisão é necessário enfatizar, pelo fato de haver sido proferida em processo de perfil eminentemente subjetivo, não se reveste de eficácia vinculante, considerado o que prescrevem o art. 102, $\S 2^{\circ}$ e o art. 103-A, "caput", da Constituição Federal, a significar, 
portanto, que aquele aresto, embora respeitabilíssimo, não se impõe à compulsória observância dos juízes e Tribunais em geral.

A decisão do Tribunal de Justiça do Estado de Minas Gerais foi com base no HC 348.598/MG do Superior Tribunal de Justiça de Relatoria do Min. Ribeiro Dantas assim ementado:

PROCESSUAL PENAL. HABEAS CORPUS IMPETRADO EM SUBSTITUIÇÃO A RECURSO PRÓPRIO. HOMICÍDIO. EXECUÇÃO PROVISÓRIA DA PENA. AUSÊNCIA DE OFENSA AO PRINCÍPIO DA PRESUNÇÃO DE INOCÊNCIA. HABEAS CORPUS NÃO CONHECIDO.

1. Esta Corte e o Supremo Tribunal Federal pacificaram orientação no sentido de que não cabe habeas corpus substitutivo do recurso legalmente previsto para a hipótese, impondo-se o não conhecimento da impetração, salvo quando constatada a existência de flagrante ilegalidade no ato judicial impugnado.

2. Conforme recente decisão do Plenário da Suprema Corte, no julgamento do HC n. 126.292/SP, a execução provisória de acórdão penal condenatório proferido em julgamento de apelação, ainda que sujeito a recurso especial ou extraordinário, não compromete o princípio constitucional da presunção de inocência. Logo, esgotadas as instâncias ordinárias, fica autorizado o recolhimento do réu para o início do cumprimento da pena, imposta ou confirmada pelo Tribunal de segundo grau, mesmo que pendente o trânsito em julgado da condenação.

3. Habeas corpus não conhecido. Fica sem efeito a liminar anteriormente deferida.

(HC 348.598/MG, Rel. Min. Ribeiro Dantas, publicado em 15/02/2016)

Segundo o Relator Min. Celso de Mello, o exame dos autos revela que se teria registrado, na espécie, possível ofensa, por parte do E. Tribunal de Justiça do Estado de Minas Gerais, à cláusula geral que veda a "reformatio in pejus" (CPP, art. 617), eis que, em recurso exclusivo do réu ordenou-se medida claramente lesiva à situação jurídica do sentenciado que sofreu grave constrição imposta ao seu "status libertatis" (BRASIL, 1941).

Aduz que o acórdão emanado do Tribunal de Justiça do Estado de Minas Gerais parece haver transgredido postulado essencial à configuração do processo penal democrático, ao inverter a fórmula da liberdade, que se expressa na presunção constitucional de inocência $\left(\mathrm{CF}\right.$, art. $5^{\circ}$, inciso LVII), degradando-a à inaceitável condição de "presunção de culpabilidade" (BRASIL, 1988).

Ressalta-se, como resulta de fragmento do voto proferido pelo Des. Revisor Eduardo Machado na Apelação Criminal $n^{\circ}$ 1.0024.09.707833-1/004, na parte em que deixou assentada a orientação que prevaleceu no julgamento de mencionado recurso:

Assim, a meu ver, o acusado inicialmente é de fato, presumidamente inocente. Entretanto, finalizada a instrução criminal e sobrevindo a sentença condenatória, esta presunção deve ser invertida. Ou seja, o acusado passa de presumidamente inocente para presumidamente culpado, incumbindo-lhe o ônus de provar o contrário.

Desta forma, não há que se falar em ofensa ao princípio de presunção de inocência (...)

Com essa inversão, o acórdão local entendeu suficiente à nulificação da presunção constitucional de inocência a mera prolação, já em primeira instância, de sentença penal condenatória recorrível, em frontal colisão com a cláusula inscrita no inciso LVII do art. $5^{\circ}$ de nossa Lei Fundamental, que erigiu o trânsito em julgado da condenação criminal em fator de legítima descaracterização do postulado do estado de inocência. 
Segundo o Relator Min. Celso de Mello, em nosso sistema jurídico, ninguém pode ser despojado do direito fundamental de ser considerado inocente até que sobrevenha o trânsito em julgado de sentença penal condenatória (CF, art. $5^{\circ}$, inciso LVII).

A consagração constitucional da presunção de inocência como direito fundamental de qualquer pessoa - independentemente da gravidade ou da hediondez do delito que lhe haja sido imputado - há de viabilizar, sob a perspectiva da liberdade, uma hermenêutica essencialmente emancipatória dos direitos básicos da pessoa humana, cuja prerrogativa de ser sempre considerada inocente, para todos e quaisquer efeitos, deve prevalecer até o superveniente trânsito em julgado da condenação criminal.

Mesmo que não se considere o argumento constitucional fundado na presunção de inocência, o que se alega por mera concessão dialética, ainda assim se mostra inconciliável com o ordenamento positivo a preconizada execução antecipada da condenação criminal, não obstante sujeita esta impugnação na via recursal excepcional (RE e/ou REsp), pelo fato de a Lei de Execução Penal, impor, como inafastável pressuposto de legitimação da execução de sentença condenatória, o seu necessário trânsito em julgado.

Daí a regra inscrita nos artigos 105 e 145 da LEP, que condicionam a execução da pena privativa de liberdade à existência de trânsito em julgado do título judicial condenatório. Daí por que, nenhuma execução de condenação criminal, mesmo se se tratar de simples pena de multa, pode ser implementada sem a existência do indispensável título judicial definitivo, resultante do necessário trânsito em julgado da sentença penal condenatória.

\section{CONSIDERAÇÕES FINAIS}

A presunção em sentido técnico define-se como sendo o mecanismo através do qual, a partir de um fato conhecido, se aceita um outro, desconhecido, sem que haja necessidade de recorrer a qualquer meio de prova. Há, na presunção, um fundamento lógico que repousa na ideia da probabilidade racional de que venha a acontecer o fato presumido, uma vez verificado o fato real. Em síntese, a presunção em sentido técnico caracteriza-se estruturalmente pelo fato de ser composta por três elementos: o fato base, o fato presumido e a relação lógico-causal entre os dois fatos, de tal forma que o segundo deriva do primeiro em virtude de uma regra máxima de experiência (VILELA, 2005, p. 81).

$\mathrm{O}$ direito à presunção de inocência é um direito fundamental com conteúdo normativo processual que se prega a todos os cidadãos, e em virtude do qual toda pessoa é inocente até que se declare sua culpabilidade ou responsabilidade em uma decisão definitiva, incumbindo aos Tribunais a tarefa de velar pelo seu cumprimento, evitando com sua atividade o descumprimento de um preceito imperativo de ordem pública de suprema aplicação, que deve estar vigente em todo tipo de jurisdição (ROMERO-ARIAS, 1985, p. 48-50).

É também um princípio que acompanha do imputado ao longo do processo penal, situando-se como afirmado entre os direitos fundamentais, e que se assume como um direito subjetivo público pertencente aos direitos das liberdades e garantias; como uma garantia subjetiva do imputado que se traduz no fato de ser reconhecido inocente enquanto a sua culpabilidade não seja provada - por quem acusa -, destruindo assim o seu estado de inocência, bem como no fato de não poder ser exercida qualquer coação pessoal contra o acusado para lá do estritamente indispensável com vista a harmonizar os interesses de liberdade e justiça (VILELA, 2005, p. 89).

Inobstante, o caráter de princípio das normas de direito fundamental deriva, não somente que, em razão dos princípios contrapostos, os direitos fundamentais estão restringidos e são restringíveis, mas que também suas restrições e a possibilidade de restringi-los, são restringidas. Uma restrição aos direitos fundamentais somente é admissível se no caso concreto aos princípios contrapostos lhes corresponde um peso maior que aquele que corresponde ao princípio de direito 
fundamental. Por isso os direitos fundamentais, em si mesmos, são restrições às suas restrições e à possibilidade de restringi-los (ALEXY, 2007, p. 257), (SANGUINÉ, 2014, p. 53).

Dessa forma, os direitos fundamentais previstos em normas constitucionais que têm a natureza de regras ou de princípios não são absolutos podendo ser relativizados em face da necessidade de consideração de outros direitos fundamentais ou de interesses públicos constitucionalmente protegidos. Isso revela que as normas que tutelam direitos fundamentais (regras ou princípios) estão em permanente interação entre si e com as demais normas constitucionais. As normas de direitos fundamentais podem ser excepcionadas ou constituir fundamento para excepcionar outras normas constitucionais, sendo em relação a elas mais nítida a aplicação da ideia de derrotabilidade de normas jurídicas (SOUZA, 2011, p. 32).

Se os direitos fundamentais não são absolutos, devem ser conciliados ou harmonizados com outros bens. Porém, nem todo bem social em abstrato ou princípio juridicamente protegível pode atuar como limite dos direitos fundamentais, mas deve tratar-se de fins sociais ou gerais que constituam em si mesmos valores constitucionalmente reconhecidos e a prioridade deve resultar da própria Constituição (SANGUINÉ, 2014, p. 54-55).

Conforme Varalda (2007, p. 81-87, 98), torna-se necessária a ampliação dos meios de defesa social em face das organizações criminosas, munidas de entes coletivos com qualificação jurídica como pessoa, aptas à realização de fatos típicos e antijurídicos. Ao contrário das organizações político-partidárias, o crime organizado não almeja conquistar os Poderes do Estado, mas sim dominá-los para manter-se por detrás, induzindo decisões. A clandestinidade possibilita à organização criminosa ampla liberdade de atuação em seus fins ilícitos. Além disso, as infrações de Direito Econômico perpetradas pelas pessoas morais são de massa, contra interesses coletivos e difusos (bem supra-individual), cuja ofensa não se mostra particularizada e precisa (dano social). A delinquência da globalização pode chegar a modificar a concepção da teoria do delito, assim como as garantias formais e materiais do direito penal e processo penal.

Caberá ao Poder Judiciário, seja através dos métodos de interpretação, seja da análise da essência e do contexto que melhor exprimem os valores da Constituição Federal quando da análise da incidência dos elementos parciais do princípio da proporcionalidade, apurar os limites de proteção da presunção de inocência e, assim, tratar diferentemente os agentes do crime organizado, cujo prejuízo jurídico se irradia imensuradamente à sociedade (VARALDA, 2007, p. 258-259).

Para Mendes (2015), o âmbito de proteção de um direito fundamental abrange os diferentes pressupostos fáticos e jurídicos contemplados na norma jurídica e a consequência comum, a proteção fundamental. Descrevem-se os bens ou objetos protegidos ou garantidos pelos direitos fundamentais. Quanto mais amplo for o âmbito de proteção de um direito fundamental, tanto mais se afigura possível qualificar qualquer ato do Estado como restrição. Ao revés, quanto mais restrito for o âmbito de proteção, menor possibilidade existe para a configuração de um conflito entre o Estado e o indivíduo.

Igualmente, não parece incompatível com a presunção de inocência (ou de não culpabilidade) que a pena passe a ser cumprida, independentemente da tramitação do recurso. $\mathrm{O}$ Brasil tem um intrincado sistema judiciário. Na base, há duas instâncias, com ampla competência para análise dos fatos e do direito. Logo acima, temos as instâncias extraordinárias - Tribunais Superiores e Supremo Tribunal. O acesso às instâncias extraordinárias é consideravelmente amplo. Não há meios eficazes para garantir adequação da força de trabalho das Cortes Superiores ao interesse do desenvolvimento da jurisprudência. A própria rejeição de recursos pela falta de repercussão geral, nas estreitas hipóteses em que cabível, demanda muito da Corte. Isso faz com que, mesmo quando desprovidos de relevância, a análise dos recursos extraordinários demore muito (MENDES, 2015).

A presunção de não culpabilidade é um direito fundamental que impõe o ônus da prova à acusação e impede o tratamento do réu como culpado até o trânsito em julgado da sentença. 
Ainda assim, não impõe que o réu seja tratado da mesma forma durante todo o processo. Conforme se avança e a culpa vai ficando demonstrada, a lei poderá impor tratamento algo diferenciado. Com isso, a execução imediata da pena privativa de liberdade na pendência de recursos extraordinários não deve ser considerada incompatível com a presunção de inocência (ou da não culpabilidade), (MENDES, 2015).

Com entendimento contrário ao HC 126.292/SP em que foi voto vencido o Ministro Celso de Mello quando do julgamento da Medida Cautelar no HC 135.100/MG firmou o entendimento de que a presunção constitucional de inocência qualifica-se como importantíssima cláusula de insuperável bloqueio à imposição prematura de quaisquer medidas que afetem ou que restrinjam a esfera jurídica das pessoas em geral. É por isso que ninguém, absolutamente ninguém, pode ser tratado como se culpado fosse antes que sobrevenha contra ele condenação penal transitada em julgado.

E aduz ainda que, o julgamento plenário do HC 126.292/SP em que se entendeu possível "a execução provisória de acórdão penal condenatória proferido em grau de apelação, ainda que sujeito a recurso especial ou extraordinário", não se reveste de eficácia vinculante, considerando o que prescrevem o art. 102, $\S 2^{\circ}$ e art. 103-A, "caput", da Constituição Federal, não se impõe à compulsória observância dos juízes e Tribunais em geral.

\section{REFERÊNCIAS}

ALEXY, Robert. Teoría de los derechos fundamentales. Trad. de Carlos Bernal Pulido. Segunda edición. Madrid: Centro de Estudios Políticos y Constitucionales, 2007.

ALEXY, Robert. Teoria dos direitos fundamentais. São Paulo: Malheiros, 2008.

BARROSO, Luís Roberto. Curso de direito constitucional contemporâneo: os conceitos fundamentais e a construção do novo modelo. São Paulo: Saraiva, 2009.

BENTO, Ricardo Alves. Presunção de inocência no processo penal. São Paulo: Quartier Latin, 2007.

BOBBIO, Norberto. A era dos direitos. Tradução Carlos Nelson Coutinho. Rio de Janeiro: Campus, 1992.

BONAVIDES, Paulo. Curso de direito constitucional. 13. ed. São Paulo: Malheiros Editores, 2003.

BOROWSKI, Martin. La estructura de los derechos fundamentales. Trad. de Carlos Bernal Pulido. Universidad Externado de Colombia, 2003.

BRASIL. Comissão de Direitos Humanos e Minorias - CDHM. Regras mínimas para a Administração da Justiça da Infância e da Juventude - Regras de Beijing (1985). Disponível em:<http://www2.camara.leg.br/atividade-legislativa/comissoes/comissões-ermanentes/cdhm /comite-brasileiro-de-direitos-humanos-e-politica-externa/RegrMinNacUniAdmJustInfJuv. html>. Acesso em 19 mar. 2016.

BRASIL. Comissão de Direitos Humanos e Minorias - CDHM. Regras mínimas para a proteção dos jovens privados de liberdade (1990). Disponível em: <//www2.camara.leg.br/atividadelegislativa/comissoes/comissoes-permanentes/cdhm/comi 
te-brasileiro-de-direitos-humanos-e-politica-externa/RegNacUniProtMenPrivLib.html>. Acesso em 19 mar. 2016.

BRASIL. Comissão de Direitos Humanos e Minorias - CDHM. Regras mínimas para o tratamento dos reclusos (1955). Disponível em: <http://www2.camara.leg.br/atividade-legis lativa/comissoes/comissoes-permanentes/cdhm/comite-brasileiro-de-direitos-humanos-e-politicaexterna/RegMinTratRec.html>. Acesso em 19 mar. 2016.

BRASIL. Constituição Federal. Constituição da República Federativa do Brasil de 1988. Publicada no Diário Oficial da União, Brasília, 05 out. 1988. Disponível em: <http://www.planalto.gov.br/ccivil_03/constituicao/constituicaocompilado.htm>. Acesso em: 13 abr. 2016.

BRASIL. Constituição Federal. Constituição da República Federativa do Brasil de 1946. Publicada no Diário Oficial da União, Brasília, 19 set. 1946. Disponível em: <http://www.planalto.gov.br/ccivil_03/Constituicao/Constituicao46.htm>. Acesso em: 13 abr. 2016.

BRASIL. Convenção Americana sobre Direitos Humanos (1969). Publicada no Diário Oficial da União, Brasília, Distrito Federal, 09 nov. 1992. Disponível em: <http://www.planalto.gov.br/ccivil_03/decreto/D0678.htm>. Acesso em: 19 mar. 2016.

BRASIL. Decreto-lei no 3.689, de 03 de outubro de 1941. Institui o código de processo penal. Publicada no Diário Oficial da União, Brasília, Distrito Federal em 13 de outubro 1941. Disponível em: < http://www.planalto.gov.br/ccivil_03/decreto-lei/Del3689Compilado.htm>. Acesso em 24 abr. 2016.

BRASIL. Lei $\mathrm{n}^{\circ}$ 8.038, de 28 de maio de 1990. Institui normas procedimentais para os processos que especifica, perante o Superior Tribunal de Justiça e o Supremo Tribunal Federal. Publicada no Diário Oficial da União, Brasília, Distrito Federal em 29 de maio 1990. Disponível em: < http://www.planalto.gov.br/ccivil_03/leis/L8038.htm>. Acesso em 24 abr. 2016.

BRASIL. Lei complementar $n^{\circ}$ 135, de 04 de junho de 2010. Altera a Lei Complementar $n^{0}$ 64, de 18 de maio de 1990, que estabelece, de acordo com o $§ 9^{-}$do art. 14 da Constituição Federal, casos de inelegibilidade, prazos de cessação e determina outras providências. Publicada no Diário Oficial da União, Brasília-DF em 07/06/2010. Disponível em: <http://www.planalto.gov.br/ccivil_03/leis/LCP/Lcp135.htm. Acesso em 24 abr. 2016.

BRASIL. Pacto Internacional de Direitos Civis e Políticos (1966). Publicado no Diário Oficial da União, Brasília, Distrito Federal, 07 jul. 1992. Disponível em: <http://www.planalto.gov.br/ccivil_03/decreto/1990-1994/d0592.htm>. Acesso em: 19 mar. 2016.

BRASIL. Supremo Tribunal Federal. Habeas Corpus no 126.292-SP, Relator Ministro Teori Zavascki, Plenário, Data do julgamento: 17 de fevereiro de 2016. Disponível em: <http://www.stf.jus.br/portal/processo/verProcessoAndamento.asp?incidente=4697570>. Acesso em: 22 abr. 2016.

CAMARGO, Monica Ovinski. Princípio da presunção de inocência no Brasil: o conflito entre punir e libertar. Rio de Janeiro: Editora Lumen Juris, 2005. 
CARRIÓ, Genaro R. Notas sobre derecho y lenguage. Segunda edición. Buenos Aires: AlbertoPerrot, 1979.

COMPARATO, Fábio Konder. A afirmação histórica dos direitos humanos. São Paulo: Saraiva, 1999.

CRESPO, Eduardo Demétrio. Do direito penal liberal ao “direito penal do inimigo". In: Revista da Associação Brasileira de Professores de Ciências Penais. São Paulo: Editora Revista dos Tribunais, ano 1, jul.-dez., 2004.

DÍEZ-PICAZO, Luis Maria. Sistema de derechos fundamentales. Segunda edición. Navarra: Thomson-Civitas, 2005.

DIMOULIS, Dimitri; MARTINS, Leonardo. Teoria geral dos direitos fundamentais. 2. ed. São Paulo: Revista dos Tribunais, 2009.

DUARTE, Maurício Nogueira. Lei de inelegibilidades, lei complementar $n^{o}$ 135/2010 e o processo eleitoral (Trabalho de Conclusão de Curso), Prof $^{a}$ Orientadora Elaine Harzheim Macedo. Pontifícia Universidade Católica do Rio Grande do Sul, 2013. Disponível em: <http://www3.pucrs.br/pucrs/files/uni/poa/direito/graduacao/tcc/tcc2/trabalhos2013_1/mauricio_ duarte.pdf>. Acesso em 07 mai. 2016.

EUR.LEX. Carta dos Direitos Fundamentais da União Europeia (2000/C 364/01). Disponível em: $\quad<$ http://eur-lex.europa.eu/legal-content/PT/TXT/PDF/?uri=CELEX:320 00X1218(01)\&from=PT>. Acesso em 20 mar. 2016.

FARIAS, Cristiano Chaves. Derrotabilidade das normas-regras (legal defeseability) no direito das famílias: alvitrando soluções para os casos extremos (extreme cases). In: Revista do Ministério Público Estadual do Pará. Belém, vol. 8, 2015.

FRANCO, Alberto Silva. Crimes hediondos. 3. ed. São Paulo: Editora Revista dos Tribunais, 1994.

GOMES, Luiz Flávio. Sobre o conteúdo processual tridimensional do princípio da presunção de inocência. In: Estudos de direito penal e processual penal. São Paulo: Editora Revista dos Tribunais, 1999.

GOMES FILHO, Antonio Magalhães. Significados da presunção de inocência. In: COSTA, José de Faria; SILVA, Marco Antonio Marques (Coord.). Direito penal especial, processo penal e direitos fundamentais: visão luso-brasileira. São Paulo: Quartier Latin, 2006.

GOMES FILHO, Antonio Magalhães. Prisão cautelar e o princípio da presunção de inocência. In: Fascículos de Ciências Penais. Porto Alegre: Sergio Antonio Fabris, ano 5, vol. 5, jan.-mar., 1992.

GOMES FILHO, Antonio Magalhães. O princípio da presunção de inocência e a prisão cautelar. São Paulo: Saraiva, 1991.

HART, Herbert. O conceito de Direito. Tradução A. Ribeiro Mendes. Lisboa: Fundação Calouste Gulbenkian, 1986. 
HESSE, Konrad. Elementos de direito constitucional da República Federal da Alemanha. 20. ed. Tradução de Luís Afonso Heck. Porto Alegre: Antonio Fabris Editor, 1998.

MENDES, Gilmar Ferreira. A presunção de não culpabilidade e a orientação do Min. Marco Aurélio. (2015). Disponível em: <http://www.migalhas.com.br/arquivos/2016/2/art2016021709.pdf>. Acesso em 22 abr. 2016.

MIRANDA, Jorge. Manual de direito constitucional. 3. ed. Coimbra: Editora Coimbra, 2000, t. IV.

MORAES, Alexandre. Direitos humanos fundamentais: teoria geral. 8. ed. São Paulo: Atlas, 2007.

OLIVEIRA, William Terra. Algumas questões em torno do novo direito penal econômico. In: Revista Brasileira de Ciências Criminais. São Paulo, ano 3, nº 11, jul.-set., 1995.

PEREIRA, Jane Reis Gonçalves. Interpretação constitucional e direitos fundamentais. Rio de Janeiro: Renovar, 2006.

PIOVESAN, Flávia. Tratados internacionais de proteção dos direitos humanos e a Constituição Federal de 1988. In: Boletim IBCCRIM. São Paulo, ano 13, nº 153, ago.-2005.

REIS, Marlón Jacinto. Direito eleitoral brasileiro. Brasília: Editora Alumnus, 2012.

ROMERO-ARIAS, Esteban. La presunción de inocencia. Pamplona: Editorial Aranzadi, 1985.

SALLES, Carlos Alberto. Reforma penal e nova criminalidade. In: Revista Brasileira de Ciências Criminais. São Paulo: Editora Revista dos Tribunais, ano 3, nº 12, out.-dez., 1995.

SANGUINÉ, Odone. Prisão cautelar, medidas alternativas e direitos fundamentais. Rio de Janeiro: Forense, 2014.

SANTOS, Juarez Cirino. Crime organizado. In: Revista Brasileira de Ciências Criminais. São Paulo, ano 11, nº 42, jan.-mar., 2003.

SARLET, Ingo Wolfgang. A eficácia dos direitos fundamentais. 10. ed. Porto Alegre: Livraria do Advogado, 1998.

SENADO FRANCÊS. Declaração dos Direitos do Homem e do Cidadão (1789). Disponível em: <http://www.senat.fr/lng/pt/declaration_droits_homme.html>. Acesso em: 20 mar. 2016.

SILVA, José Afonso. Curso de direito constitucional. 22. ed. rev. e atual. São Paulo: Malheiros Editora, 2000.

SILVA, Virgílio Afonso. Direitos fundamentais: conteúdo essencial, restrições e eficácia. 2. ed. São Paulo: Editora Malheiros, 2010.

SOUZA, Rodrigo Telles. A distinção entre regras e princípios e a derrotabilidade das normas de direitos fundamentais. In: Boletim Científico ESMPU. Brasília-DF, ano 10, nº 34, jan.-jun., 2011. 
UNESCO. Declaração Universal dos Direitos do Homem (1948). Disponível em: <http://unesdoc.unesco.org/images/0013/001394/139423por.pdf>. Acesso em: 20 mar. 2016.

VARALDA, Renato Barão. Restrição ao princípio da presunção de inocência: prisão preventiva e ordem pública. Porto Alegre: Sergio Antonio Fabris Editor, 2007.

VILELA, Alexandra. Considerações acerca da presunção de inocência em direito processual penal. Reimpressão. Coimbra: Coimbra Editora, 2005.

WOLFGANG BÖCKENFÖRD, Ernst. Estudios sobre el Estado de Derecho y la democracia. Madrid: Trotta, 2000.

ZÍLIO, Rodrigo López. Direito eleitoral: noções preliminares, elegibilidade e inelegibilidade, processo eleitoral (da convenção à prestação de contas), ações eleitorais. 3. ed. Porto Alegre: Editora Verbo Jurídico, 2012. 